\title{
The Influence of E-Learning on Individual and Collective Empowerment in the Public Sector: An Empirical Study of Korean Government Employees
}

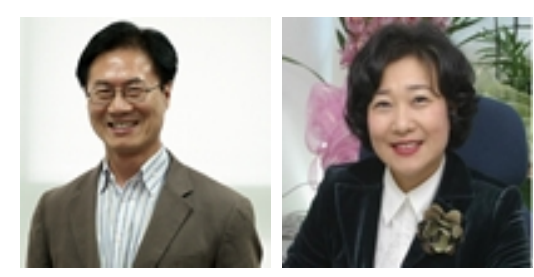

Mann Hyung Hur ${ }^{1}$ and Yeonwook $\mathrm{Im}^{2}$

${ }^{1}$ Chung-Ang University, Korea, Republic of, ${ }^{2 H a n y a n g}$ Cyber University, Korea, Republic of

\section{Abstract}

Our study explores the influence of e-learning on individual and collective empowerment by using data collected from e-learning class participants of Korea's Cyber-Education Center. For the survey, a questionnaire was sent to each of the 41 central ministries' education and training officers (ETO) via email. The ETOs distributed the questionnaire to individuals in their ministries who have taken elearning classes offered by the Cyber-Education Center during the first half of 2012. Out of more than 1,000 e-learning class attendees, 161 responded to the questionnaire survey.

A set of multiple regression models was employed to explore significant predictors of government employees' individual and collective empowerment in e-learning environments. Using existing literature on empowerment theories, a set of 16 questions was developed. A factor analysis was conducted to condense 16 individual variables into several large categories. Four factors including meaning, competence, selfdetermination, and collective empowerment were extracted from the 16 questions. The first three equations stood for individual empowerment and the last one for collective empowerment. Each of the four factors was utilized as a dependent variable in the multiple regression analysis.

Each regression model uncovered its own set of variables that played a role in empowerment. The predictor variables of the meaning dimension were more widely split than those of the competence dimension or the self-determination dimension and 
collective empowerment. Only one independent variable-preference of e-learning class to offline class-was associated with all four dependent variables. However, modalities of e-learning activity, which were expected to be a significant predictor of empowerment, were not associated with any of the four dependent variables. In addition, lecture types of the e-learning class were also expected to be a significant predictor of empowerment but were only associated with the competence dimension.

Keywords: Individual empowerment; collective empowerment; e-learning; online discussion; government employment; self-determination

\section{Introduction}

E-learning stands for a form of electronically designed, distributed, and facilitated learning activities. It includes instruction delivered via all electronic media, such as the Internet, intranet, satellite broadcasts, audio/video tape, interactive TV, and CD-ROM (Govindasamy, 2002). E-learning can be conceptualized in five dimensions: a new tool that incorporates equipment, hardware, and software; a facilitator of interaction; learning; a reduction in distance; and a collaborative enterprise (Stein et al., 2011). Unlike traditional in-class learning, e-learning is most likely to reference out-ofclassroom educational experiences, although in-class educational activities experienced via information and communications technology (ICT) can sometimes be described as a form of e-learning. In addition, e-learning includes blended learning known as a mixed type of learning via the online and offline learning environments. This unique device of learning has been recognized as an intervention that can facilitate organizational learning (Phang et al., 2008) and individual empowerment (Gandhi, 2011) in the public sector.

E-learning offers unprecedented opportunities for learners. Its primary advantage is that it enables students to participate in learning activities from anywhere in the world and at any time provided a computer and internet connection are available. Nowadays, devices such as smart-phones or smart-pads provide even mobile learning opportunities. Many countries have developed national e-learning policies and elearning infrastructure designed to give direction and lead the way (Anderson et al., 2006; Brown et al., 2007; Stein et al., 2011). In Korea, the Central Officials Training Institute (COTI) opened the Cyber-Education Center in 2009 to provide virtual classes for government employees. Since e-learning is quite flexible in terms of space and time, government employees can even take on-the-job training without leaving their offices. Each year, thousands of government employees enroll in e-learning courses via the Cyber-Education Center.

In the government sector, the trained incapacity is recognized as a long-standing problem. Government employees work in a bureaucratic environment and are accustomed to following their supervisors' directions or prepared manuals; therefore, 
they tend to gradually lose their creative thinking abilities (Adler, 2012; Turner, 1976). Government employees in Korea are usually recognized as well-qualified individuals before they start working for the government because they have to pass a highly competitive exam. However, they subsequently appear incapable of doing anything much with their academic backgrounds and potential, which might lower the feeling of achievement associated with their work and the level of citizen satisfaction.

Empowerment in an organization corresponds to employees' ability to recognize their timidity, create autonomy through boundaries, and build teams for problem resolutions (Terblanche, 2003). A variety of pedagogical designs, content types, and lecture types for optimizing e-learning have been developed and are available. Based on these devices, e-learning can offer vivid and authentic learning materials using multimedia technology. However, these e-learning devices have rarely been examined to determine how effectively they can contribute to the improvement of knowledge transfer, knowledge enrichment, and empowerment. Although e-learning has been implemented in the educational and training field for government employees, so far little evaluation on its effectiveness has been conducted. Our study explores the influence of e-learning on individual and collective empowerment by using data collected from e-learning class participants of COTI's Cyber-Education Center.

\section{Literature Review}

\section{E-Learning}

\section{Definition.}

Researchers and practitioners have yet to agree on a common definition for e-learning. The term e-learning is frequently confused with other learning modes, such as distance learning, open learning, and open and distance learning (ODL), although they are not interchangeable based on their meanings (Moore, Dickson-Deane, \& Gaylen, 2011). Elearning literally refers to the learning activities based on an electronic delivery means, whereas distance learning refers to an instructional delivery mode in which an instructor is physically located in a different place from the learner as well as possibly providing the instruction at disparate times (Moore, Dickson-Deane, \& Gaylen, 2011, p. 129). Open learning means "either that distance education is the prevailing method used by the teaching system or that there are no prerequisites for access, even for degree programs" (Trindade, Carmo, \& Bidarra, 2000, p. 2).

E-learning, in a narrow sense, is defined as strictly being accessible using technological tools that are computer-based, web-based, web-distributed, or web-capable (Nichols, 2003) and considered part of ODL. However, e-learning, in a broad sense, not only covers content and instructional methods delivered via CD-ROM, the Internet, or an 
intranet (Benson et al., 2002; Clark, 2002) but also includes audio- and videotape, satellite broadcasts, interactive TV, and mobile devices. In this sense, it is used as a synonym of ODL that diverges from distance learning (van Zyl, Els, \& Blignaut, 2013). In our study, e-learning refers to a type of learning that is synonymous with ODL.

\section{Characteristics.}

E-learning, in terms of being synonymous with ODL, is understood from many perspectives and used with different meanings (Stein et al., 2011). Its applications and processes include computer-based learning, web-based learning, virtual education opportunities, and digital collaboration. Content is delivered via the Internet, intranet/ extranet, audio or video tape, satellite TV, CD-ROM, or mobile devices. It can be self-paced or instructor-led and includes media in the form of text, images, animations, and streamed video and audio.

Four general categories can be identified in e-learning: 1) technology-driven, 2) delivery system-oriented, 3) communication-oriented, and 4) educational paradigm-oriented (Sangrà et al., 2012). From the perspective of the technology-driven category, e-learning is the use of ICT for learning. It is an ICT-based learning setting of taking a course online using a modem, wireless, or cable connection to access course material from a computer, phone, or handheld device. From the perspective of the delivery systemoriented category, e-learning is the delivery of a learning, training, or education program by electronic instruments ( $\mathrm{Li}$ et al., 2009). The communication-oriented category considers e-learning to be a communication, interaction, and collaboration tool in an ICT-based environment. Finally, the educational paradigm-oriented category considers e-learning as a new way of learning or as an improvement of an existing educational paradigm by using ICT (Sangrà et al., 2012). E-learning is oriented toward the construction of a user-friendly learning setting by using ICT. Through e-learning, students can access e-learning content wherever and whenever they like. They can also repeat the entire learning process as the courses are recorded and stored, and repeated access to content is usually allowed (Im \& Bautista, 2009). All four categories have to focus on the achievement of learning excellence.

\section{Modalities of e-learning activity.}

Modalities of e-learning activity refer to the types of e-learners' activities. In a broad sense, they can be divided into two categories: individualized self-paced e-learning and group-based e-learning. Individualized self-paced e-learning refers to the situation where a learner is, by himself or herself, accessing learning resources such as a database and course content. This category can be further divided into open and closed individualized self-paced e-learning. The former involves accessing learning resources via an intranet or the Internet, whereas a learner in the latter type uses learning resources such as a database or a computer-assisted package offline while not connected to an intranet or the Internet. 
Group-based e-learning refers to the situation where groups of learners are working together in an ICT-based setting. This category can also be further divided into two types: synchronous and asynchronous group-based e-learning. Learners in the former type are usually working together in real time via an intranet or the Internet whereas those in the latter type are working over an intranet or the Internet and exchanges among participants occur with a time delay. A critical difference exists between individualized self-paced e-learning and group-based e-learning: Interactions in elearning are very limited in the former regardless of being online or offline, but widely open in the latter regardless of being synchronous or asynchronous. Collaboration is usually realized through tasks and discussions. The depth of collaboration is perceived to vary, depending on assignment type and learner motivation (Leppisaari et al., 2013).

E-learning activities are closely related to content delivery style. Lectures in the e learning setting can be delivered in a very interactive way. Lecture types in the elearning setting can actually be more diversified than those in traditional offline classes. To promote visual attention, both static and moving images can be presented at the same time. Educational games can also be utilized in an interactive way. A learner physically and/ or mentally has a role in creating an outcome in games. His decision, in return, results in a reward or consequence. In such ways, e-learning can provide more diversified lecture types for learners so that learning excellence can be effectively achieved.

\section{E-learning objectives.}

Learning excellence, summarized as effective knowledge transfer, is one objective of elearning. Knowledge transfer remains one of the most important goals in learning. In the context of ICT and incorporated learning, e-learning is a key enabler to knowledge transfer (Owens \& Price, 2010). The meaning of learning excellence has changed since the emergence of the concepts of heutagogy and andragogy with Web 2.0 (Blaschke, 2012) to include empowerment (Halawi et al., 2009).

According to heutagogy originally rooted in andragogy, as the development of e-learning is successfully achieved, e-learning participants gradually move from passive to selfdirected learners and then on to self-determined learners; at the same time, the selfdetermined learners progress in maturity and autonomy. More mature learners require less instructor control and course instruction and can be more self-directed and selfdetermined in their learning (Blaschke, 2012, p. 60); at the same time, they acquire both competencies and capabilities. "Competency can be understood as proven ability in acquiring knowledge and skills, while capability is characterized by learner confidence in his or her competency" (Blaschke, 2012, p. 59). The two concepts are also usually cited as the key elements of empowerment (Thomas \& Velthouse, 1990). However, in the field of e-learning, the relationship between e-learning and empowerment has rarely been explored. In the e-learning literature, empowerment and its components as well as developmental processes have rarely been investigated, although significant materials 
exist in the psychology, education, and social work and social welfare research fields.

\section{Empowerment}

Empowerment is conceived as a multidimensional social learning process that helps people gain control over their lives (Page \& Czuba, 1999). Empowerment is operative at various levels-namely, individual, interpersonal, organizational, community, and collective (Hur, 2006). Boehm and Staples (2004) emphasized personal and collective dimensions whereas Dodd and Gutierrez (1990), Lee (1994), and Gutierrez (1990) examined personal, interpersonal, and institutional or political dimensions. However, the interpersonal dimension can be included in the collective dimension because the term interpersonal has a connotation of collectiveness. The institutional or political dimensions can be represented as part of the collective dimension. Therefore, empowerment can be examined in the context of both individual and collective aspects (Hur, 2006).

\section{Individual empowerment and its dimensions.}

Individual empowerment relates to the way in which people think about themselves as well as the knowledge, capacities, skills, and mastery they actually possess (Staples, 1990, p. 32). Various authors have presented the dimensions of individual empowerment in their own way, but the components might be expressed along with the array of Thomas and Velthouse (1999) and Spreitzer et al. (1997). Four dimensions can be extracted from the review of various literature-namely, a sense of meaning, competence, self-determination, and impact (Hur, 2006).

A sense of meaning refers to the notions of consciousness rising (Moreau, 1990) and critical consciousness (Lee, 1994). In a conceptual view, a sense of meaning can become a greenhouse in which the concept of competence is generated (Thomas \& Velthouse, 1990). Competence refers to an individual's ability to perform a job properly. Selfdetermination is considered to be one of the most critical factors in the components of individual empowerment. It refers to a state of understanding in terms of what to do in a crisis situation or in the resolution of particular problems. The notion of impact falls between individual empowerment and collective empowerment because impact is outcome-oriented toward organizations and society as a whole.

\section{Collective empowerment and its dimensions.}

Collective empowerment refers to a process by which individuals join together, help one another, learn together, and develop skills for collective action (Boehm \& Staples, 2004; Fetterson, 2002). Individual empowerment sometimes conflicts with the development of collective empowerment, when empowerment is not effectively operating. Although individuals can become more empowered personally through the process of personal development, they cannot always be effective in helping to build their group's collective empowerment. Personal empowerment should be consistent with collective 
empowerment to improve the value of social and economic justice more effectively (Staples, 1999).

Collective empowerment develops when people join in action together to resolve particular social problems and achieve social change. Groups become empowered through collective action (Staples, 1990; Hur, 2006) in a collaborative way. In carefully reviewing the conceptual interrelations between the dimensions of collective empowerment, four components can be extracted: collective belonging, working together for collective goals, gaining forces to achieve shared goals, and community building among group members (Hur, 2006).

\section{Relationship between E-Learning and Empowerment}

The objectives of learning, regardless of its type (e.g., traditional in-class learning or elearning online) go beyond knowledge transfer. As described in the concept of heutagogy, empowerment should be considered as just one of these objectives. Schoolbased learning might focus on knowledge transfer, knowledge enrichment, and knowledge enhancement. However, the objectives of elearning have to be expanded beyond those of traditional school-based learning. E-learning can not only concentrate on the three previously mentioned traditional objectives, but also has to focus on knowledge synthesis and empowerment. Therefore, the final objective of e-learning has to be oriented toward individual and collective empowerment.

E-learning emerged in the field of education approximately 20 years ago. Since then, a variety of pedagogical designs for optimizing e-learning have been developed. These designs include scenario-based learning, goal-based learning, problem-based learning, and case-based learning. A variety of e-learning content types have been developed, including text, audio, visuals, games, and blended types. E-learning has also been utilized in the workplace as its benefits have been identifiable from the workplace point of view (Batakka-Busquests \& Oacheco-Bernal, 2013; Berge \& Giles, 2006).

E-learning has been recognized as an appropriate educational mechanism for excluded individuals and communities having few, if any, degrees of freedom to engage with open learning to help reduce or remove these disempowering conditions (Lane, 2009). Some authors (Palloff \& Pratt, 1999) have argued that students in an online learning environment learn what it takes to pace themselves in order to get the job done. In this process, they become increasingly confident in their abilities and feel empowered to work in a manner that best suits them. However, e-learning has rarely been practiced for individual and collective empowerment in the real world except for the Sunhara Walmart project in India (Jimenez, 2012), an agricultural development and empowerment initiative that works with 2,500 women farmers in Ghaziabad and Agra on overall socioeconomic empowerment. The project was established by Agribusiness Systems International with funding from the Walmart Foundation and has implemented e-learning centers to counter the constraints that women face, such as 
illiteracy, transportation difficulties, and low market prices.

In addition, empirical studies to test the relationship between e-learning and empowerment have rarely been conducted, and only a couple of studies have been published in journals. One was about empowering disabled people through e-learning. The paper was not written based on empirical data, but rather to address the challenges to helping people with intellectual disabilities easily learn the activities of daily living (Barrera et al., 2008). The other paper was a review study on e-learning for the empowerment of teaching and learning in higher education. It described the basic ideas of e-learning, modalities of e-learning, media influences in the e-learning process, and various pedagogical designs of e-learning (Gandhi, 2011).

Our study explores the relationship between elearning and empowerment based on data collected from government employees with experience in e-learning activities. We conducted a set of multiple regression analyses to explore how effectively e-learning has contributed to participants' individual and collective empowerment. For these regression analyses, various dimensions of individual and collective empowerment were employed as dependent variables, while attributes of e-learning, modalities of elearning, and lecture types of e-learning were used as independent variables.

\section{Methodology}

\section{Data Collection}

A questionnaire was developed to survey both individual and collective empowerment among central government employees. Korea's central government consists of 41 ministries, of which 21 are headed by ministers and the other 20 are headed by vice ministers. The survey was carried out with the cooperation of each ministry's education and training officer (ETO). A questionnaire was sent to the ETOs of 41 ministries via email. The ETOs distributed the questionnaire to individuals in their ministries who have taken e-learning classes offered by the COTI during the first half of 2012. Out of more than 1,000 e-learning class attendees, 161 responded to the questionnaire survey.

\section{Dependent Variables}

In this study, a set of multiple regression models was employed to explore significant predictors of government employees' individual and collective empowerment in e learning environments. Using existing literature on empowerment theories, a set of 16 questions was developed. These questions related to one of four components of individual and collective empowerment (i.e., meaning or awareness of limited potential, competence, self-determination, and collective empowerment). A factor analysis was 
conducted to condense 16 individual variables into several large categories. As can be seen in Table 1, four factors were extracted from the 16 questions. Factor 1 was composed of three questions and could be characterized as the meaning factor; the reliability coefficient (alpha) of Factor 1 was 0.949 , showing strong internal consistency among the three variables. This meaning variable, representing a dimension of individual empowerment, refers to an awareness of an individual's limited potential to change the circumstance (Robins et al., 1998, p. 91).

Factor 2 constituted three questions and represented the competence factor; the reliability coefficient of Factor 2 was 0.960 , also representing strong intercorrelations among the three variables. Factor 3 was composed of five questions and characterized as the self-determination factor; the reliability coefficient was 0.968 , showing a strong internal consistency among the five variables. Factor 4 consisted of five questions and was characterized as the collective empowerment factor; the reliability coefficient was 0.980, representing strong intercorrelations among the five variables. Therefore, the original set of 16 questions was condensed into four factors, which individually stand for the dimensions of both individual and collective empowerment. The former three factors correspond to individual empowerment and the last factor stands for collective empowerment. Each of the four factors' coefficients was utilized as dependent variables for this study.

Table 1

Rotated Component Matrix: Individual Empowerment and Collective Empowerment

\begin{tabular}{|c|c|c|c|c|c|}
\hline \multirow{2}{*}{ Questions } & \multicolumn{3}{|c|}{ Individual empowerment } & \multirow{3}{*}{$\begin{array}{c}\text { Factor } 4 \\
\text { Collective } \\
\text { empowerment }\end{array}$} & \multirow{3}{*}{ Alpha } \\
\hline & \multirow{2}{*}{$\begin{array}{l}\text { Factor } 1 \\
\text { Meaning }\end{array}$} & \multirow{2}{*}{$\begin{array}{c}\text { Factor } 2 \\
\text { Competence }\end{array}$} & \multirow{2}{*}{$\begin{array}{c}\text { Factor } 3 \\
\text { Self- } \\
\text { determination }\end{array}$} & & \\
\hline $\begin{array}{l}\text { The e-learning class } \\
\text { contributed to the } \\
\text { improvement of: }\end{array}$ & & & & & \\
\hline $\begin{array}{l}\text { Understanding } \\
\text { capabilities of } \\
\text { knowledge in } \\
\text { current workplace } \\
\text { affairs }\end{array}$ & .855 & .287 & .219 & .241 & \multirow{3}{*}{.949} \\
\hline $\begin{array}{l}\text { Learning capabilities } \\
\text { of knowledge in } \\
\text { current workplace } \\
\text { affairs }\end{array}$ & .871 & .240 & 226 & .285 & \\
\hline $\begin{array}{l}\text { Knowledge } \\
\text { accumulation in } \\
\text { current workplace } \\
\text { affairs }\end{array}$ & .777 & .380 & .323 & .150 & \\
\hline $\begin{array}{l}\text { Involvement } \\
\text { competence in } \\
\text { current workplace } \\
\text { affairs }\end{array}$ & .438 & .765 & .268 & .300 & \multirow[t]{2}{*}{.960} \\
\hline Competence in the & .404 & .774 & .310 & 299 & \\
\hline
\end{tabular}




\begin{tabular}{|c|c|c|c|c|c|}
\hline $\begin{array}{l}\text { implementation of } \\
\text { current workplace } \\
\text { affairs }\end{array}$ & & & & & \\
\hline $\begin{array}{l}\text { Involvement } \\
\text { competence in new } \\
\text { workplace affairs }\end{array}$ & .353 & .751 & .357 & .300 & \\
\hline $\begin{array}{l}\text { Capabilities of self- } \\
\text { expression }\end{array}$ & .285 & .312 & .726 & .454 & \multirow{5}{*}{.968} \\
\hline $\begin{array}{l}\text { Capabilities of } \\
\text { selecting better } \\
\text { alternatives }\end{array}$ & .402 & .260 & .742 & .354 & \\
\hline $\begin{array}{l}\text { Capabilities of } \\
\text { making decisions on } \\
\text { particular problems }\end{array}$ & .343 & .221 & .741 & .437 & \\
\hline $\begin{array}{l}\text { Capabilities of } \\
\text { taking challenges }\end{array}$ & .180 & .292 & .753 & .423 & \\
\hline $\begin{array}{l}\text { Capabilities of } \\
\text { taking initiatives }\end{array}$ & .218 & .244 & .726 & .485 & \\
\hline $\begin{array}{l}\text { Capabilities of } \\
\text { making relations } \\
\text { with others }\end{array}$ & .235 & .248 & .573 & .659 & \multirow{5}{*}{.980} \\
\hline $\begin{array}{l}\text { Capabilities of } \\
\text { working together } \\
\text { with others }\end{array}$ & .243 & 212 & .373 & .841 & \\
\hline $\begin{array}{l}\text { Capabilities of } \\
\text { building teams }\end{array}$ & .237 & .198 & .400 & .836 & \\
\hline $\begin{array}{l}\text { Capabilities of } \\
\text { building coalitions }\end{array}$ & .184 & .288 & .365 & .842 & \\
\hline $\begin{array}{l}\text { Capabilities of } \\
\text { solving problems } \\
\text { with others }\end{array}$ & .252 & .286 & .383 & .797 & \\
\hline
\end{tabular}

\section{Independent Variables}

Independent variables were selected from e-learning class participation frequencies, attributes of an e-learning class, objectives of taking an e-learning class, preference of an e-learning class to an offline class, modalities of an e-learning class, and lecture types of an e-learning class. Participation frequencies refer to the number of times that an individual government employee has taken e-learning classes for the first half of 2012. The attributes of e-learning can be summarized as three As, referring to its features of engaging in elearning anytime, anywhere, and in any classes. To explore the relationship between the three attributes and employees' empowerment, two dummy variables were selected (see Table 2).

The objectives of government employees' taking an e-learning class can be summarized as improvement of current job performance, career development, and promotion. In order to explore the influence of these respective objectives on their empowerment, two dummy variables were employed (see Table 2). The variable "preference of e-learning 
class to offline class" was measured with a seven-point scale ( 1 = dislike e-learning class very much compared to an offline class, $7=$ like elearning class very much). Based on the possibility of interactive learning with class participants, the modalities of the elearning activity in this study were categorized into individualized self-paced e-learning and group-based e-learning. Interactive learning with class participants is limited in the former setting whereas it is widely open in the latter setting. One dummy variable was employed for this variable. In addition, one dummy variable was utilized for lecture types of e-learning, as this variable can be classified into delivery class and discussion class. In the delivery setting, the interaction between students and lectures is limited whereas it is widely open in the discussion setting.

Table 2

Independent Variables and Their Measurements

\begin{tabular}{|c|c|c|c|}
\hline \multicolumn{2}{|c|}{ Independent variables } & Measurements & Name \\
\hline \multicolumn{2}{|c|}{ Participation frequencies } & $\begin{array}{l}\text { Number of } \\
\text { participation }\end{array}$ & Num \\
\hline \multirow{3}{*}{$\begin{array}{l}\text { Attributes of } \\
\text { e-learning class }\end{array}$} & Anytime & Yes $=1$, no $=0$ & D1 \\
\hline & Anywhere & Yes $=1, \mathrm{no}=0$ & $\mathrm{D} 2$ \\
\hline & Any class & $\mathrm{n} / \mathrm{a}^{1}$ & \\
\hline \multirow{3}{*}{$\begin{array}{l}\text { Objectives of } \\
\text { taking an e- } \\
\text { learning class }\end{array}$} & Improvement of current job performance & Yes $=1, \mathrm{no}=0$ & D3 \\
\hline & Career development & Yes $=1$, no $=0$ & $\mathrm{D} 4$ \\
\hline & Promotion & $\mathrm{n} / \mathrm{a}^{2}$ & \\
\hline \multicolumn{2}{|c|}{ Preference of e-learning class to offline class } & 7-point scale & Pref \\
\hline \multirow{2}{*}{$\begin{array}{l}\text { Modalities of } \\
\text { e-learning } \\
\text { activity }\end{array}$} & Individualized self-paced e-learning & Yes $=1$, no $=0$ & D5 \\
\hline & Group-based e-learning & $\mathrm{n} / \mathrm{a}^{3}$ & \\
\hline \multirow{2}{*}{$\begin{array}{l}\text { Lecture types of } \\
\text { e-learning class }\end{array}$} & Delivery class & Yes $=1$, no $=0$ & D6 \\
\hline & Discussion classes & $\mathrm{n} / \mathrm{a}^{4}$ & \\
\hline
\end{tabular}

Note. n/ a1: "Any class" served as the baseline for comparison with the two other attributes noted. $\mathrm{n} / \mathrm{a}^{2}$ : "Promotion" served as the baseline for comparison with the two other attributes noted. n/ $\mathrm{a}^{3}$ : "Group-based e-learning" served as the baseline for comparison with "individualized self-paced elearning." $\mathrm{n} / \mathrm{a}^{4}$ : "Discussion class" served as the baseline for comparison with "delivery class."

\section{Statistical Analysis}

Each of the four factors extracted from the factor analysis was utilized as a dependent variable in the multiple regression analysis in this study. The first three equations stood for individual empowerment and the last one for collective empowerment. The four equations of the multiple regression analysis employed in this study were as follows:

Meaning Scale $=\mathrm{a}+\mathrm{bNum}+\mathrm{cD} 1+\mathrm{dD} 2+\mathrm{eD} 3+\mathrm{fD} 4+\mathrm{gPref}+\mathrm{hD} 5+\mathrm{iD} 6$

Competence Scale $=\mathrm{a}+\mathrm{bNum}+\mathrm{cD} 1+\mathrm{dD} 2+\mathrm{eD} 3+\mathrm{fD} 4+\mathrm{gPref}+\mathrm{hD} 5+\mathrm{iD} 6$ 
Self-Determination Scale $=\mathrm{a}+\mathrm{bNum}+\mathrm{cD} 1+\mathrm{dD} 2+\mathrm{eD} 3+\mathrm{fD} 4+\mathrm{gPref}+\mathrm{hD} 5+\mathrm{iD} 6$

Collective Empowerment Scale $=\mathrm{a}+\mathrm{bNum}+\mathrm{cD} 1+\mathrm{dD} 2+\mathrm{eD} 3+\mathrm{fD} 4+\mathrm{gPref}+\mathrm{hD} 5+$ iD

\section{Results}

\section{Government Employees' Individual and Collective Empowerment}

The level of government employees' individual and collective empowerment was drawn from a simple descriptive statistical analysis based on the four dimensions of individual and collective empowerment drawn from a factor analysis. The results showed that government employees have been more greatly empowered on an individual basis than a collective basis. As seen in Table 3, the average level of individual empowerment was significantly higher than that of collective empowerment. The former was 4.55 on a seven-point scale, while the latter was 4.21 , and the difference was statistically significant. In addition, they were more greatly empowered in the meaning dimension than in the other two as well as in the competence dimension than in the selfdetermination dimension. Table 3 indicates that the average level of the meaning dimension was greater than the competence dimension, and the competence dimension was greater than the self-determination dimension. The differences among the three dimensions were statistically significant.

In carefully reviewing these results, an interesting sequentiality emerged in the levels of both the three dimensions of individual empowerment and the individual and collective empowerment. Reasoning inductively based on this sequentiality, it can be concluded that government employees were empowered in the awareness of their potential or capabilities before being empowered in their competence. Self-determination was achieved based on two components (e.g., meaning and competence). Government employees were also collectively empowered based on their individual empowerment. 
Table 3

Government Employees' Individual and Collective Empowerment

\begin{tabular}{|c|c|c|c|c|c|c|c|}
\hline \multicolumn{2}{|c|}{ Dimensions of empowerment } & Mean & $\begin{array}{l}\text { Std } \\
\text { Div. }\end{array}$ & Paired-sample & t(sig.) & Mean & t(sig.) \\
\hline \multirow{3}{*}{$\begin{array}{l}\text { Individual } \\
\text { Empowerment }\end{array}$} & Meaning & 4.83 & .99 & $\begin{array}{l}\text { Meaning vs. } \\
\text { competence }\end{array}$ & \begin{tabular}{|l|}
6.338 \\
$(.000)$ \\
\end{tabular} & \multirow{3}{*}{4.55} & \multirow{4}{*}{$\begin{array}{l}5.178 \\
(.000)\end{array}$} \\
\hline & Competence & 4.49 & 1.06 & $\begin{array}{l}\text { Competence vs. } \\
\text { self- } \\
\text { determination }\end{array}$ & $\begin{array}{r}2.783 \\
(.006)\end{array}$ & & \\
\hline & $\begin{array}{l}\text { Self- } \\
\text { determination }\end{array}$ & 4.30 & 1.21 & $\begin{array}{l}\text { Meaning vs. self- } \\
\text { determination }\end{array}$ & $\begin{array}{l}7.372 \\
(.000)\end{array}$ & & \\
\hline \multicolumn{2}{|c|}{ Collective empowerment } & 4.21 & 1.31 & 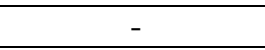 & & 4.21 & \\
\hline
\end{tabular}

\section{Influential Variables on Individual and Collective Empowerment}

\section{Overview.}

Four multiple regression analyses were conducted to explain the variability of the four dependent variables. Each model uncovered its own set of variables that played a role in empowerment. As seen in Table 4, the predictor variables of the meaning dimension were more widely split than those of the competence dimension or the selfdetermination dimension and collective empowerment.

Only one independent variable-preference of e-learning class to offline class-was associated with all four dependent variables. However, modalities of e-learning activity, which were expected to be a significant predictor of empowerment, were not associated with any of the four dependent variables. In addition, lecture types of the e-learning class were also expected to be a significant predictor of empowerment but were only associated with the competence dimension. In a broad sense, government employees' preference of e-learning to an offline class mattered significantly. Commitment to an elearning class rather than an offline class could be described as a critical predictor of individual and collective empowerment. Participation frequencies could be identified as a significant predictor of the meaning dimension, but they were not a significant predictor of the other three dimensions.

\section{Variables associated with the meaning dimension.}

Four of the eight independent variables in the multiple regression analysis were significantly associated with the meaning dimension. These four variables were split into participation frequencies, attributes of an e-learning class, objectives of taking an elearning class, and preference of an e-learning class to an offline class. 
The meaning dimension showed a significant relationship with the participation frequencies variable. Government employees who have attended e-learning classes more frequently showed a higher level of the meaning dimension. One attribute of the elearning class, the convenience of attending anytime, was identified as a significant predictor associated with the meaning dimension. Thus, those who would buy an elearning class due to the convenience of attending anytime showed a higher level of the meaning dimension than those who would buy a class due to one of the other two attributes (i.e., anywhere and any class). One objective of taking an e-learning class, career development, was identified as a significant predictor associated with the meaning dimension. This result indicated that those who would take an e-learning class to pursue career development showed a lower level of the meaning dimension than those who would take it for the purpose of the other two objectives (i.e., improvement of current job performance and promotion). Finally, the variable preference of an elearning class to an offline class was explored as a significant predictor of the meaning dimension; those who found themselves more attracted to an e-learning class than an offline class showed a higher level of the meaning dimension.

To summarize these findings, government employees could be more greatly empowered in the meaning dimension if they tried to participate in e-learning classes more frequently, buy the convenience of attending an elearning class anytime, attend the class for the purpose of improving in their current job performance and promotion, and be more attracted to an e-learning class than an offline class. In these situations, they would possibly promote their understanding and learning capabilities of knowledge in their workplace affairs and knowledge promotion in current workplace affairs.

\section{Variables associated with the competence dimension.}

Three of the eight independent variables in the multiple regression analysis were significantly associated with the competence dimension. The predictors of the competence dimension were split into objectives of taking an e-learning class, preference of an e-learning class to an offline class, and lecture types of an e-learning class.

The competence dimension showed a significant relationship with one objective of taking an e-learning class: improvement of current job performance. This finding indicated that those who would take an e-learning class for the purpose of improvement of current job performance showed a higher level of competence than those who would take it for the purpose of career development and promotion. The preference of an elearning class to an offline class variable was also identified as a significant predictor of the competence dimension, meaning that those who found themselves more attracted to an e-learning class than an offline class showed a higher level of competence. Finally, the lecture types of an e-learning class were also identified as a significant predictor of the competence dimension, meaning that those who would prefer a delivery class to a discussion class showed a lower level of the competence dimension. 
Thus, government employees could be more greatly empowered in the competence dimension if they tried to take an elearning class to improve their current job performance, to be more attracted to an e-learning class than an offline class, and to participate in the discussion class rather than the delivery class. In these situations, they could end up promoting their involvement competence in current workplace affairs, competence in the implementation of current workplace affairs, and involvement competence in new workplace affairs.

\section{Variables associated with self-determination.}

Only two of the eight independent variables showed a significant relationship with the self-determination dimension: attributes of an e-learning class and preference of an elearning class to an offline class. One attribute of an e-learning class, convenience of attending anytime, was identified as a significant predictor associated with the selfdetermination dimension. This result represented that those who would buy an elearning class due to the convenience of attending anytime showed a higher level of the self-determination dimension than those who would buy one of the other two attributes of an e-learning class (i.e., anywhere and any class). The preference of an e-learning class to an offline class variable was also explored as a significant predictor of the selfdetermination dimension, meaning that those who found themselves more attracted to an e-learning class than an offline class showed a higher level of self-determination.

In summary, government employees could be more greatly empowered in the selfdetermination dimension if they tried to buy the convenience of attending an e-learning class anytime and to be more attracted to an e-learning class than an offline class. In these situations, they would possibly promote their capabilities of self-expression, selecting better alternatives, making decisions on particular problems, taking challenges, and taking initiatives.

\section{Variables associated with collective empowerment.}

Only two of the eight independent variables showed a significant relationship with collective empowerment: objectives of taking an e-learning class and preference of an elearning class to an offline class. Career development as an objective of taking an elearning class was identified as a significant predictor of collective empowerment. This result indicated that those who would take an e-learning class for the purpose of career development showed a lower level of collective empowerment than those who would take it for the other two purposes (i.e., improvement of current job performance and promotion). The preference of an e-learning class to an offline class variable was identified as a significant predictor of collective empowerment, meaning that those who found themselves more attracted to an e-learning class than an offline class showed a higher level of collective empowerment.

The term collective empowerment, from a theoretical perspective, refers to various efforts, such as team building, collaboration, and coalition building. Government 
employees could be more greatly empowered in collective empowerment if they tried to attend the class for the purpose of improving their current job performance and promotion and to be more attracted to an e-learning class than an offline class. In these contexts, they would promote their capabilities of making relations with others, working together with others, building teams with their peer groups, building coalitions, and effectively solving issues with others.

Table 4

Summary of Individual and Collective Empowerment Predictors

\begin{tabular}{|c|c|c|c|c|c|c|c|c|c|c|c|c|c|}
\hline \multirow{3}{*}{\multicolumn{2}{|c|}{ Independent variables }} & \multicolumn{9}{|c|}{ Individual empowerment } & \multirow{2}{*}{\multicolumn{3}{|c|}{$\begin{array}{c}\text { Collective } \\
\text { empowerment }\end{array}$}} \\
\hline & & \multicolumn{3}{|c|}{ Meaning } & \multicolumn{3}{|c|}{ Competence } & \multicolumn{3}{|c|}{$\begin{array}{c}\text { Self- } \\
\text { determination } \\
\end{array}$} & & & \\
\hline & & $\mathrm{b}$ & $\mathrm{t}$ & $\mathrm{p}$ & b & $\mathrm{t}$ & $\mathrm{p}$ & $\mathrm{b}$ & $\mathrm{t}$ & $\mathrm{p}$ & $\mathrm{b}$ & $\mathrm{t}$ & $\mathrm{p}$ \\
\hline \multicolumn{2}{|l|}{ Constant } & \begin{tabular}{|c|}
- \\
2.283 \\
\end{tabular} & - & .002 &.$\overline{-}$ & -1.169 & .224 & $1 . \overline{339}$ & $\begin{array}{c}- \\
1679 \\
\end{array}$ & .096 & $\begin{array}{c}- \\
1378 \\
\end{array}$ & $\begin{array}{c}- \\
1793 \\
\end{array}$ & .075 \\
\hline \multicolumn{2}{|c|}{ Participation frequencies } & .007 & 1774 & $.078^{*}$ & $\begin{array}{c}- \\
.006\end{array}$ & $\begin{array}{c}- \\
1509\end{array}$ & .134 & .003 & $\mid-.748$ & .456 & .001 & .228 & .820 \\
\hline \multirow{2}{*}{\begin{tabular}{|l|} 
Attributes \\
of \\
e-learning \\
class a $^{\text {a }}$ \\
\end{tabular}} & Anytime & .520 & 2.140 & $.034^{*}$ & .410 & 16161 & .109 & -.446 & 1698 & $.092^{*}$ & -.019 & -.077 & .939 \\
\hline & Anywhere & .141 & .437 & .663 & .304 & .898 & .371 & -.476 & $\begin{array}{c}- \\
1360 \\
\end{array}$ & .176. & .308 & .912 & .364 \\
\hline \multirow{2}{*}{$\begin{array}{l}\text { Objectives } \\
\text { of taking } \\
\text { e-learning } \\
\text { class }^{b}\end{array}$} & $\begin{array}{l}\text { Improvement } \\
\text { of current job } \\
\text { performance }\end{array}$ & $|-.067|$ & -.329 & .742 & .372 & 1739 & $.084^{*}$ & .023 & .105. & .916 & 103. & .481. & .631 \\
\hline & $\begin{array}{l}\text { Career } \\
\text { development }\end{array}$ & $\mid-.435$ & 1809 & $.073^{*}$ & .348 & $1 . \overline{-}$ & .168 & .335 & 1287 & 200 & -.443 & 1769 & $.079 *$ \\
\hline \multicolumn{2}{|c|}{$\begin{array}{l}\text { Preference of e-learning } \\
\text { class to offline class }\end{array}$} & .445 & 4.289 & $.000 *$ & .336 & 3.102 & $.002 *$ & .233 & 2.077 & $.040^{*}$ & .375 & 3.463 & $.001^{*}$ \\
\hline $\begin{array}{l}\text { Modalities } \\
\text { of } \\
\text { e-learning } \\
\text { activity c }\end{array}$ & $\begin{array}{l}\text { Individualized } \\
\text { self-paced } \\
\text { e-learning }\end{array}$ & .063 & .603 & .548 & .026 & -.240 & .811 & .047 & .411 & .682 & .030 & |-.227 & .783 \\
\hline $\begin{array}{l}\text { Lecture } \\
\text { types of } \\
\text { e-learning } \\
\text { class d }\end{array}$ & Delivery class & -.179 & -.366 & .715 & $\begin{array}{c}- \\
.845\end{array}$ & $\begin{array}{c}- \\
1654\end{array}$ & $.100^{*}$ & .695 & 1314 & 191. &.$\overline{-}$ & -.400 & .690 \\
\hline \multicolumn{2}{|l|}{$\mathrm{R}^{2}$} & \multicolumn{3}{|c|}{.198} & \multicolumn{3}{|c|}{.147} & \multicolumn{3}{|c|}{.116} & \multicolumn{3}{|c|}{.146} \\
\hline
\end{tabular}

${ }^{*} \mathrm{p} \leq 0.10,{ }^{* *} \mathrm{p} \leq .05,{ }^{* * *} \mathrm{p} \leq .01$

Note. a: "Any class" serves as the baseline for comparison. b: "Promotion" serves as the baseline for comparison. c: "Group-based e-learning" serves as the baseline for comparison. d: "Discussion class" serves as the baseline for comparison. Refer to Table 2 . 


\section{Discussion}

E-learning has many valuable usages. It has extended education arenas from a limited offline classroom to cyberspace and has expanded education opportunities from students to all members of society. Moreover, e-learning might ultimately contribute to changing the course of education from knowledge transfer and enhancement to the promotion of empowerment. This study demonstrated the possibilities that e-learning would influence the promotion of individual and collective empowerment. In a broad sense, both attributes of e-learning and objectives of taking e-learning classes were significantly associated with individual empowerment, and taking an e-learning class and preference of an e-learning class to an offline class were identified as significant predictors of collective empowerment. These findings could offer evidence that the elearning mechanism contributed to the promotion of individual and collective empowerment.

However, contrary to our expectations, both modalities of e-learning activity and lecture types of e-learning could not be considered significant predictors of individual and collective empowerment. Only the lecture types of an e-learning class were associated with the competence dimension of individual empowerment. Group-based e-learning rather than individualized self-paced e-learning could provide participants with better opportunities to be collectively empowered, but it was not significantly associated with individual and collective empowerment. These results might stem not from the availability of various modalities and lecture types, but from the lack of vitalization of these modalities and lecture types. In other words, e-learning in an interactive way among class participants as well as between lecturers and students is not yet significantly associated with empowerment, but will be possibly associated with empowerment under the condition of their vitalization.

Government employees have been sequentially empowered from acquiring the sense of meaning and competence to becoming self-determined and from gaining individual empowerment to achieving collective empowerment. As Thomas and Velthouse (1990) mentioned, a sense of meaning is likely to become a greenhouse in which the concept of competence is generated and growing as a result. Both meaning and competence seem to become a greenhouse in which the concept of competence is generated and thus growing. Ultimately, individual empowerment is a greenhouse in which collective empowerment is generated and growing. According to the empirical analysis in this study, a relatively lower level of empowerment was more easily gained than a higher level of empowerment in terms of individual empowerment. In addition, individual empowerment was more easily acquired than collective empowerment.

Each of the four dimensions of empowerment has its own predictors. No unique patterns were found in the predictors. However, lower levels of empowerment dimensions were associated with a relatively large number of predictors whereas higher levels of empowerment dimensions were correlated with a relatively small number of 
predictors. These results indicate that government employees were not efficiently empowered at the higher dimensions of empowerment, although lower dimensions can become a greenhouse for higher dimensions, and that e-learning might not be an effective learning instrument in achieving a higher level of empowerment, but it could be in achieving a lower level of empowerment.

As previously mentioned, only one independent variable-preference of an e-learning class to an offline class-was associated with all four dependent variables. Meanwhile, modalities of e-learning activity were not associated with any of the four dependent variables. In addition, lecture types of elearning were associated only with the competence dimension. Delivering e-learning in an interactive way between participants and lecturers could contribute to the improvement of government employees' competence level. In a broad sense, neither modality of e-learning activity or lecture types of e-learning were a critical predictor of individual and collective empowerment. It did not matter whether government employees selected an individualized self-paced elearning activity or a group-based e-learning activity. Rather, their preference of elearning to an offline class mattered significantly. Commitment to an e-learning class rather than an offline class could be described as a critical predictor of individual and collective empowerment. Participation frequency could be identified as a significant predictor of the meaning dimension, but it was not a significant predictor of the other three dimensions.

\section{Conclusions}

The findings in this study showed that e-learning could be described as an effective mechanism for government employees' individual and collective empowerment. However, the results fell short of our expectations. The ultimate objective of e-learning being provided for government employees was to overcome a sort of trained incapacity problem that is widespread in the government sector. Government employees being empowered at lower levels might not effectively cope with trained incapacity as well as when carrying out creative jobs. Customized e-learning devices for the improvement of self-determination and collective empowerment need to be developed and made available for government employees. More exquisite and elaborate strategies in the development and operation of e-learning are also needed.

Online discussion classes, if designed to encourage interactivity, can enhance the promotion of empowerment. In our study, these classes were not found to be positively associated with any types of empowerment. However, it might be hasty to conclude that discussion classes do not matter significantly in the promotion of empowerment. An effective e-learning environment can afford various modalities of interaction between the three macro components: students, instructors, and content (Anderson, 2004). Based on these three components, six typologies of interaction can be presented: 
student-student, student-instructor, student-content, instructor-instructor, instructor-content, and content-content. These typologies have to be appropriately used as the basis of the educational process in an online discussion environment (Balaji \& Chakrabarti, 2010). Typological readiness has not been verified in this study. Thus, further studies are needed on this issue.

This paper discussed an empirical study that was conducted, but with a limited target area (i.e., Korea's government sector). Individuals in the private sectors or in other educational environments might respond to e-learning in a different way. Further studies are required to generalize theories found in our study. 


\section{References}

Adler, P. S. (2012). The sociological ambivalence of bureaucracy: From Weber via Gouldner to Marx. Organization Science, 23(1), 244-266.

Anderson, B., Brown, M., Murray, F., Simpson, M., \& Mentis, M. (2006). Global picture, local lessons: E-learning policy and accessibility. Retrieved from http:// cms.steo.govt.nz/NR/rdonlyres/C1EBB9EB-9122-4F82-94BBA713CDEE9D02/0/AndersonFinalReport.pdf.

Anderson, T. (2004). Towards a theory of online learning. In T. Anderson \& F. Elloumi (Eds.), Theory and practice of onlinelearning (pp. 33-60). Edmonton: AB: Athabasca University Press.

Balaji, M. S., \& Chakrabarti, D. (2010). Student interactions in online discussion forum: Empirical research from 'media richness theory' perspective. J ournal of Interactive Online Learning, 9(1), 1-22.

Barrera, C., Olga C. S., Gutierrez, E., Boticario, J . G., Moranchel, J ., Roldan, J . R., \& Casas, T. (2008). Empowering disabled people: E-learning challenges for independent live. aDeNu Research Group, Artificial Intelligence Department, Computer Science School, Spanish National University of Distance Education.

Batalla-Busquests, J-M., \& Pacheco-Bernal, C. (2013). On-the-job e-learning: Workers' attitudes and perceptions. The International Review of Research in Open and Distance Learning, 14(1), 40-64.

Benson, L., Elliot, D., Grant, M., Holschuh, D., Kim, H., et al. (2002). Usability and instructional design heuristics for e-learning evaluation. In Proceedings of World Conference on Educational Multimedia, Hypermedia and Telecommunications 2002 (pp. 1615-1621). Presented at the World Conference on Educational Multimedia, Hypermedia and Telecommunications (EDMEDIA), Chesapeake, VA: AACE.

Berge, Z. L., \& Giles, L. (2006). Implementing and sustaining e-learning in the workplace. International J ournal of Information and Communication Technology Education, 2(4), 64-75.

Blaschke, L. M. (2012). Heutagogy and lifelong learning: A review of heutagogical practice and self-determined learning. The International Review of Research in Open and Distance Learning, 13(1), 56-71.

Boehm, A., \& Staples, L. H. (2004). Empowerment: The point of view of customer. Families in Society, 85(2), 270-280. 
Brown, M., Anderson, B., \& Murray, F. (2007). E-learning policy issues: Global trends, themes and tensions. In ICT: providing choices for learners and learning. Proceedings ascilite. Singapore. Retrieved from http:// www.ascilite.org.au/ conferences/ singapore07/ procs/ brown.pdf.

Clark, R. (2002). Six principles of effective e-learning: What works and why. The eLearning Developer's J ournal, 1-10.

Dodd, P., \& Gutierrez, L. M. (1990). Preparing students for the future: A power perspective on community practice. Administration in Social Work, 14(2), 6378.

Govindasamy, T. (2002). Successful implementation of e-learning pedagogical considerations. The Internet and Higher Education, 4(3), 287-299.

Gutierrez, L. M. (1990). Working with women with color: An empowerment perspective. Social Work, 35(2), 149-153.

Halawi, L. A., McCarthy, R. V., \& Pires, S. (2009). An evaluation of e-learning on the basis of Bloom's Taxonomy: An exploratory study. J ournal of Education for Business, 84(6), 374-380.

Hur, M. H. (2006). Empowerment in terms of theoretical perspectives: Exploring a typology of the process and components across disciplines. J ournal of Community Psychology, 34(5), 523-540.

Im, Y., \& Bastusta, D. (2009). Conceptualizing a cyber university model in support of effective ESD. Asia Pacific Collaborative Education J ournal, 5(1).

J imenez, A. (2012). Empowering women farmers through e-learning in India. Eagriculture. Retrieved from http:// www.e-agriculture.org/news/ empoweringrural-women-farmers-through-e-learning-india.

Lane, A. (2009). The impact of openness on bridging educational digital divides. International Review of Research in Open and Distance Learning, 10(5), 1726.

Lee, L. (1994). The empowerment approach to social work practice. New York: Columbia University.

Leppisaari, I., Herrington, J ., Vainio, L., \& Im, Y. (2013). Authentic e-learning in a multicultural context. J ournal of Interactive Learning Research, 24(1), 53-73.

Moore, J . L., Dickson-Deane, C., \& Galyen. K. (2011). E-Learning, online learning, and distance learning environments: Are they the same? Internet and Higher Education, 14, 129- 135. 
Nichols, M. (2003). A theory of e-learning. Educational Technology \& Society, 6(2), 110.

Owens, J . D., \& Price, L. (2010). Is e-learning replacing the traditional lecture? Educational and Training J ournal, 52(2), 128-139.

Page, N., \& Czuba, C. E. (1999). Empowerment: What is it? J ournal of Extension, 37(5), 24-32.

Palloff , R. M., \& Pratt, K. (1999). Building learning communities in cyberspace: Effective strategies for the online classroom. San Francisco, CA: J ossey-Bass.

Phang, C. W., Kankanhalli, A., \&Ang, C. (2008). Investigating organizational learning in egovernment projects: A multi-theoretic approach. J ournal of Strategic Information Systems, 17, 99-123.

Sangrà, A., Vlachopoulos, D., \& Cabrera, N. (2012). Building an inclusive definition of elearning: An approach to the conceptual framework. The International Review of Research in Open and Distance Learning, 13(2), 140-159.

Spreitzer, G. M., Kizilos, M. A., \& Nason, S. W. (1997). A dimensional analysis of talk about disability. American J ournal of Community Psychology, 28(5), 671-695.

Staples, L. H. (1990). Powerful ideas about empowerment. Administration in Social Work, 14(2), 29-42.

Stein, S. J ., Shephard, K., \& Harris, I. (2011). Conceptions of e-learning and professional development for e-learning held by tertiary educators in New Zealand. British J ournal of Educational Technology, 42(1), 145-165.

Terblanche, F. (2003). Empowering people in organization. Mousaion, 21(2), 127-137.

Thomas, K., \&Velthouse, B. (1990). Cognitive elements of empowerment: An interpretive model intrinsic task motivation. Academy of Management Review, $15,666-681$.

Trindade, A. R., Carmo, H., \& Bidarra, E. (2000). Current developments and best practice in open and distance learning. International Review of Research in Open and Distance Learning, 1(1), 1-25.

Turner, B. S. (1976). Manpower planning or trained incapacity? Australian J ournal of Public Admtration, 34(3), 258-280. 
van Zyl, J . M., Els, C. J ., \& Blignaut, A. S. (2013). Development of ODL in a newly industrialized country according to face-to-face contact, ICT, and e-readiness. International Review of Research in Open and Distance Learning, 14(1), 84105.

\section{Athabasca University $\mathbf{Z}$}

(9) (1) 